\title{
PENGARUH KEGIATAN EKSTRAKURIKULER, PERCAYA DIRI DAN LITERASI EKONOMI TERHADAP MINAT BERWIRAUSAHA SISWA SMPN DI SURABAYA
}

\author{
Supriyanto, SMP Negeri 40 Surabaya \\ supriyantobambe@gmail.com
}

\begin{abstract}
ABSTRAK
Penelitian ini bertujuan untuk menganalisis pengaruh kegiatan ekstrakurikuler, percaya diri dan literasi ekonomi terhadap minat berwirausaha siswa SMPN di Surabaya.Penelitian ini merupakan penelitian kuantitatif. Sampel penelitian ini sebanyak 233 yang diambil dengan tekniksimple random sampling. Analisis data menggunakan regresi linear berganda.Hasil uji hipotesis secara parsial menunjukkankegiatan ekstrakurikuler dan literasi ekonomi berpengaruh signifikan pada minat berwirausaha siswa SMPN di Surabaya sedangkan percaya diri tidak berpengaruh signifikan pada minat berwirausaha siswa SMPN di Surabaya. Hasil uji hipotesis secara simultan menujukkan kegiatan ekstrakurikuler, percaya diri dan literasi ekonomi secara simultan berpengaruh signifikan terhadap minat berwirausaha siswa SMPN di Surabaya.
\end{abstract}

Kata Kunci:kegiatan ekstrakurikuler, percaya diri, literasi ekonomi, minat berwirausaha

\begin{abstract}
This study aimed to analyze the effect of extracurricular activities, confidence and economic literacy of the students' interest in entrepreneurship junior high schools in Surabaya. This research is quantitative. This study of 233 samples were taken by simple random sampling technique. Analysis of data using multiple linear regression. Partial results of hypothesis testing showed extracurricular activities and economic literacy significant effect on students ' interest in entrepreneurship junior high schools in Surabaya while confident no significant effect on students' interest in entrepreneurship junior high schools in Surabaya . Simultaneous hypothesis test results showed extracurricular activities, confidence and economic literacy simultaneously significant effect on students' interest in entrepreneurship junior high schools in Surabaya .

Keywords : extracurricular activities, confident, economic literacy, interest in entrepreneurship
\end{abstract}

\section{PENDAHULUAN}

Terkait dengan minat berwirausaha, menurut Lambing dan Kuehl (2007), hasil penelitian terbaru menunjukkan ada empat hal yang memengaruhi keputusan berwirausaha, yaitu diri pribadi, lingkungan budaya, kondisi sosial, dan kombinasi dari ketiganya. Sedangkan menurut Hisrichdkk (2008) dan Alma (2011), faktor yang memengaruhi minat wirusaha adalah lingkungan pendidikan, kepribadian seseorang dan lingkungan keluarga. Minat berwirausaha seseorang dapat dilihat dari dua indikator utama yaitu: (1) seberapa kuat upaya seseorang untuk berani 
mencoba melakukan aktivitas kewirausahaan; (2) seberapa banyak upaya yang direncanakan seseorang untuk melakukan aktivitas kewirausahaan (seperti aktivitas dalam mengelola waktu dan keuangan untuk tujuan berwirausaha).

Lingkungan pendidikan sebagaimana dikatakan oleh Hisrich dkk (2008) dan Alma(2011) sebagai salah satu faktor yang mempengaruhi minat wirausaha juga bisa menumbuhkan rasa percaya diri, dimana rasa percaya diri ini juga menjadi salah satu faktor yang mempengaruhi minat wirausaha.

Dari berbagai penelitian di atas, bisa dipahami betapa besar peran lingkungan pendidikan dalam menyediakan ruang bagi pembelajaran wirausaha siswa melalui kegiatan ekstrakurikuler yang menumbuhkan rasa percaya diri dan kegiatan intrakurikuler melalui mata pelajaran Ilmu Pengetahuan Sosial-Ekonomi yang meningkatkan literasi ekonomi siswa sehingga dari itu semua menimbulkan minat berwirausaha pada diri siswa. Itulah salah satu urgensi pendidikan wirausaha di sekolah bagi anak-anak Indonesia.

Dari penjelasan Hisrich dan Alma di atas, bisa dipahami bahwa literasi ekonomi yang diperoleh dari lingkungan pendidikan, dalam hal ini bisa diperoleh dari mata pelajaran Ilmu Pengetahuan Sosial-Ekonomi dan kegiatan ekstrakurikuler yang bermuatan kewirausahaan, memiliki hubungan yang sangat erat dan sangat berpengaruh terhadap munculnya minat berwirausaha siswa. Disamping Literasi ekonomi, lingkungan pendidikan juga menyediakan ruang yang sangat luas untuk siswa mengembangkan bakat dan minatnya dalam wadah kegiatan ekstrakurikuler, dimana salah satu atau beberapa diantara kegiatan ekstrakurikuler tersebut bisa diarahkan untuk melatih jiwa bisnis siswa sehingga muncul minat berwirausaha dalam diri para siswa tersebut.

Di Croatia, hasil penelitian Gregov dkk (2004) menyatakan bahwa pelajaran ekonomi di sekolah bisnis dapat memunculkan literasi ekonomi dan aktivitas wirausaha. Bila pembelajaran ekonomi berjalan dengan baik, maka akan menghasilkan literasi ekonomi yang baik. Tentunya hal ini akan terjadi jika guru ekonomi yang mengajar juga berkualifikasi baik. Guru ekonomi yang memiliki kualifikasi kurang baik menyebabkan tingkat literasi ekonomi (economic literacy) masyarakat menjadi rendah.

Salah satu kegiatan ekstrakurikuler yang sedang populer di berbagai sekolah di Surabaya adalah ekstrakurikuler yang terkait dengan Program Adiwiyata/PLH. Program Adiwiyata/PLH ini adalah program kerjasama antara Kementerian Pendidikan dan Kebudayaan dengan Kementerian Lingkungan Hidup yang ingin mewujudkan Visi Sekolah Peduli dan Berbudaya Lingkungan. Kedua kementerian ini secara periodik menggelar berbagai lomba yang terkait dengan Adiwiyata/PLH ini. Beberapa sekolah di Surabaya telah berhasil menjadi Sekolah Adiwiyata dan menjuarai berbagai lomba yang terkait dengan Program Adiwiyata tersebut.

Surabaya sebagai kota yang sangat peduli pada pelestarian lingkungan dan berkali-kali berhasil mempertahankan piala Adipura, melalui Pemerintah Kota Surabaya memberikan perhatian yang sangat besar terhadap isu lingkungan ini. Berbagai kegiatan digelar untuk menjaga kelestarian lingkungan. Dimana dalam setiap kegiatan tersebut selalu melibatkan warga sekolah (guru dan siswa) mulai dari SD hingga SMA/SMK yang ada di Surabaya. Selain menggelar berbagai kegiatan pelestarian lingkungan, Pemerintah Kota Surabaya melalu Dinas Pendidikan Kota Surabaya juga mewajibkan setiap sekolah untuk membuat dan 
melaksanakan Program Adiwiyata/PLH dengan dukungan dana dari BOS maupun tambahan dari APBD melalui BOPDA.

Di SMP Negeri 40 Surabaya, untuk melaksanakan Program Adiwiyata/PLH tersebut, sekolah telah membentuk Kegiatan Ekstrakurikuler yang diberi nama "Cilung" yang merupakan singkatan dari Cinta Lingkungan. Kegiatan yang dilakukan diantaranya adalah berbagai kegiatan pelestarian lingkungan di kawasan sekolah dan sekitarnya, Pembentukan Bank Sampah, Produksi dan Pemasaran Teh Asoka, Produksi berbagai Handicraft/ Cinderamata berbahan daur ulang, Produksi dan Pemasaran Es Lios, Pembuatan kertas daur ulang, dan sebagainya. Sedangkan di SMPN 28 Surabaya kegiatan PLH ini dilaksanakan dengan membentuk berbagai POKJA (Kelompok Kerja) dimana salah satu POKJA tersebut adalah POKJA yang melaksanakan ecopreneur dengan produk budi daya jamur yang kemudian diolah menjadi Cokelat Jamur, Nugget Jamur, Es Krim Jamur dan Brownis Jamur.

Dari berbagai kegiatan yang dilakukan oleh SMP Negeri 28 dan 40 Surabaya ini diharapkan dapat melatih siswa untuk peduli lingkungan dan menyadarkan mereka tentang betapa berharganya lingkungan kita. Termasuk kesadaran/literasi ekonomi, membangkitkan rasa percaya diri dan menumbuhkan minat berwirausaha yang sangat berkaitan dengan pendidikan ekonomi.

Salah satu Kegiatan Ekstrakurikuler Cinta Lingkungan adalah Bank Sampah dimana kegiatan utamanya adalah menabung, meskipun yang ditabung adalah sampah, tetap saja bisa bernilai uang. Kegiatan ini tentunya sangat bermafaat untuk meningkatkan literasi ekonomi siswa terutama terkait dengan kegiatan menabung tersebut. Hasil penelitian sebelumnya yang dilakukan oleh Yunus dkk. (2010) menjelaskan bahwa literasi ekonomi berhubungan positif dengan niat menabung karena individu atau pun keluarga tidak mau berusaha menabung disebabkan minimnya pengetahuan ekonomi. Rendahnya pengetahuan semakin memperburuk keadaan apabila tidak segera diperbaiki melalui upaya yang berkesinambungan untuk meningkatkan literasi ekonomi.

Meningkatnya rasa percaya diri, literasi ekonomi dan minat berwirausaha ini wajar untuk diharapkan karena berbagai kegiatan yang dilakukan dalam Kegiatan Ekstrakurikuler Cinta Lingkungan/PLH ini hampir semuanya bisa bernilai ekonomis. Operasional Bank Sampah bisa mendatangkan uang bagi nasabahnya, Pembuatan dan pemasaran Teh Asoka, Cokelat, Nugget, Es Krim dan Brownis Jamur mampu mendatangkan keuntungan finansial, pembuatan dan pemasaran handicraft daur ulang juga bisa menambah kas dan atau uang saku mereka. Selain itu berbagai kegiatan bernilai ekonomis tersebut juga membutuhkan pengelolaan yang baik dari sisi usaha/bisnis. Oleh karena itu kegiatan usaha/bisnis mereka ini bisa membawa hasil berupa terlatihnya mereka untuk mengelola usaha/bisnis sehingga diharapkan munculnya minat berwirausaha dari para anggota Kegiatan Ekstrakurikuler Cinta Lingkungan ini.

Dari hasil observasi yang peneliti lakukan di kedua sekolah tersebut sudah terlihat minat siswa yang cukup tinggi untuk berwirausaha. Siswa terlihat begitu antusias dan penuh percaya diri dalam menjalankan usaha tersebut. Hasil observasi juga menunjukkan bahwa siswa sudah memiliki literasi ekonomi yang memadai. Hal ini terlihat dari kemampuan siswa dalam mengelola usaha yang menghasilkan keuntungan dari kegiatan ecopreneur ini. Dari fenomena tersebut maka penelitian ini bertujuan untuk menganalisis pengaruh kegiatan 
ekstrakurikuler, percaya diri dan literasi ekonomi terhadap minat berwirausaha siswa SMPNegeri di Surabaya.

Definisi wirausaha menurut Meridith (2000) adalah seorang yang mempunyai kemampuan melihat dan memiliki kesempatan - kesempatan bisnis, mengumpulkan sumber-sumber daya yang dibutuhkan guna mengambil keuntungan dari padanya dan mengambil tindakan yang tepat guna memastikan kesuksesan. Sedangkan menurut Robert Hisrich (Alma, 2013) wirausaha merupakan proses penciptaan sesuatu yang berbeda dengan mengabdikan seluruh waktu dan tenaganya disertai dengan menanggung resiko keuangan, kejiwaan, sosial dan menerima balas jasa dan bentuk uang dan kepuasaan pribadi.

Meridith (2000) mengatakan ciri-ciri dan sifat-sifat berikut memberikan sebuah profil dari wirausaha:

Tabel 1. Karakteristik Wirausaha

\begin{tabular}{|l|l|l|}
\hline No & Ciri2 & Watak \\
\hline 1 & Percaya diri & $\begin{array}{l}\text { Keyakinan, ketidaktergantungan, } \\
\text { individualitas dan optimism. }\end{array}$ \\
\hline 2 & $\begin{array}{l}\text { Berorientasi pada tugas dan } \\
\text { hasil }\end{array}$ & $\begin{array}{l}\text { Kebutuhan akan prestasi, berorientasi laba, } \\
\text { ketekunan dan ketabahan, tekad kerja keras, } \\
\text { mempunyai dorongan kuat, energetic dan } \\
\text { inisiatif. }\end{array}$ \\
\hline 3 & Pengambilan resiko & $\begin{array}{l}\text { Kemampuan mengambil resiko, suka pada } \\
\text { tantangan }\end{array}$ \\
\hline 4 & Kepemimpinan & $\begin{array}{l}\text { Bertingkah laku seperti pemimpin, dan } \\
\text { dapat bergaul dengan orang lain. }\end{array}$ \\
\hline 5 & Keorisinilan & Inovatif, kreatif dan fleksibel \\
\hline 6 & Berorientasi ke masa depan & $\begin{array}{l}\text { Pandangan kedepan, perspektif } \\
\text { demiliki keyakinan bahwa hidup sama }\end{array}$ \\
\hline 7 & Jujur dan tekun & \multicolumn{2}{|l}{} \\
\hline
\end{tabular}

Sumber: Meridith (2000)

Slameto mendefinisikan minat adalah suatu rasa lebih suka dan rasa ketertarikan kepada suatu hal dan beraktivitas, tanpa ada yang menyuruh. Minat pada dasarnya adalah penerimaan akan adanya suatu hubungan antara diri sendiri dengan yang ada di luar diri. Semakin kuat dan dekat hubungan tersebut maka semakin besar minat (Slameto, 2010).

Minat menurut As'ad adalah sikap yang membuat orang senang terhadap obyek, situasi atau ide-ide tertentu. Hal ini diikuti oleh perasaan senang dan kecenderungan untuk mencari obyek yang disenangi itu. Pola-pola minat seseorang merupakan salah satu faktor yang menentukan kesesuaian orang dengan pekerjaannya. Minat orang terhadap jenis pekerjaannya yang berbeda-beda (As'ad, 2004).

Berdasarkan dari beberapa pendapat di atas dapat disimpulkan bahwa minat adalah perasaan tertarik, senang atau kecendurungan hati seorang yang penuh kesadaran kepada suatu pilihan tertentu dengan berpartisipasi atau mencari obyek yang disenanginya itu 
Menurut Fuadi (2009:93), minat berwirausaha adalah keinginan, ketertarikan, serta kesediaan untuk bekerja keras atau berkemauan keras untuk berusaha secara maksimal untuk memenuhi kebutuhan hidupnya tanpa merasa takut dengan resiko yang akan terjadi, serta berkemauan keras untuk belajar dari kegagalan. Mahesa \& Rahardja (2012) menguraikan bahwa minat berwirausaha adalah kecenderungan hati dalam diri subjek untuk tertarik menciptakan suatu usaha yang kemudian mengorganisir, mengatur, menanggung resiko dan mengembangkan usaha yang diciptakannya sendiri. Sedangkan Budiati dkk (2012) menyatakan bahwa intensi kewirausahaan atau minat menjadi wirausaha dapat diartikan sebagai proses pencarian informasi yang dapat digunakan untuk mencapai tujuan pembentukan suatu usaha.

Pengukuran minat terhadap pekerjaan dapat dilakukan dengan berbagai cara, salah satunya menurut Sumarwan (2003) adalah dengan struktur pembentukkan minat berperilaku, yaitu:

1. Komponen Kognitif

Komponen kognitif adalah pengetahuan dan persepsi yang diperoleh melalui pengalaman dengan suatu obyek, sikap dan informasi dari berbagai sumber. Pengetahuan dan persepsi biasanya berbentuk kepercayaan dan kepercayaan yang maksudnya adalah adanya rasa percaya bahwa suatu obyek sikap mempunyai berbagai atribut dan perilaku yang spesifik.

2. Komponen Afektif

Komponen afektif memnggambarkan perasaan dan emosi seseorang terhadap obyek. Perasaan dan sikap seseorang merupakan evaluasi menyeluruh terhadap obyek sikap. Komponen minat, afektif disini menunjukkan penilaian langsung dan umum terhadap suatu obyek.

Perasaan dan emosi seseorang terutama ditujukan kepada obyek secara keseluruhan, bukan perasaan dan emosi kepada atribut-atribut yang dimiliki oleh suatu obyek. Perasaan dan emosi digambarkan dengan ungkapan dua sifat yang berbeda guna mengevaluasi obyek tersebut.

3. Komponen Konatif

Komponen konatif menunjukkan tindakan seseorang atau kecenderungan perilaku terhadap suatu obyek. Aspek konatif kepribadian ditandai dengan tingkah laku yang bertujuan dan impuls untuk berbuat. Konasi berupa bereaksi, berusaha, berkemauan, dan berkehendak. Konasi merupakan wujud dari kognisi dan afeksi dalam bentuk tingkah laku. Komponen konatif adalah aspek volisional, yang berhubungan dengan kebiasaan dan kemauan bertindak.

Dari teori tersebut, maka dalam penelitian ini pengukuran minat berwirausaha dilakukan dengan indikator komponen kognitif, komponen afektif dan komponen konatif.

Ekstrakurikuler adalah kegiatan pendidikan yang dilakukan oleh peserta didik di luar jam belajar kurikulum standar sebagai perluasan dari kegiatan kurikulum dan dilakukan di bawah bimbingan sekolah dengan tujuan untuk mengembangkan kepribadian, bakat, minat, dan kemampuan peserta didik yang lebih luas atau di luar minat yang dikembangkan oleh kurikulum. Berdasarkan definisi tersebut, maka kegiatan di sekolah atau pun di luar sekolah yang terkait dengan tugas belajar suatu mata pelajaran bukanlah kegiatan ekstrakurikuler (Kemendikbud, 2013). 
Kegiatan ekstrakurikuler yang dimaksud dalam penelitian ini adalah Kegiatan Ekstarkurikuler Cinta Lingkungan/PLH. Kegiatan ekstrakurikuler Cinta Lingkungan/PLH merupakan salah satu pelaksanaan Program Adiwiyata/PLH di sekolah yang memiliki kegiatan utama berupa ecoschool dan ecopreneur. Dalam penelitian ini yang akan menjadi fokus kajian adalah kegiatan ecopreneur saja. Ecopreneur adalah kegiatan wirausaha yang memusatkan diri pada usaha yang ramah lingkungan, berusaha melakukan bisinis yang memberikan keuntungan kepada lingkungan (Wibowo, 2010).

Keberhasilan suatu kegiatan ekstrakurikuler sangat ditentukan oleh keterlibatan siswa sebagai pelaku utama dari kegiatan tersebut. Menurut Fredricks dkk (2004) keterlibatan siswa didefinisikan melalui tiga dimensi, yaitu: 1) keterlibatan perilaku (behavior engagement) yang berfokus pada partisipasi siswa seperti berusaha, bersungguh-sungguh, konsentrasi, memberi perhatian, mematuhi peraturan, dan berkontribusi dalam diskusi di kelas; 2) keterlibatan emosi (emotional engagement) yang berfokus pada reaksi emosi siswa; dan 3) keterlibatan kognitif (cognitive engagement) yang berfokus pada investasi siswa dalam belajar dan strategi regulasi diri yang digunakan.

Perilaku siswa yang menunjukkan keterlibatan dalam belajar meliputi berusaha, bertahan dalam menghadapai tugas yang menantang, berkontribusi dalam diskusi di kelas, konsentrasi, mengajukan pertanyaan, dan memperhatikan kegiatan belajar di kelas. Keterlibatan emosi adalah reaksi afektif siswa di dalam kelas mencakup minat, bosan, senang, sedih, cemas. Dalam penelitian yang dilakukan oleh Skinner dan Belmont, siswa yang terlibat dalam kegiatan di kelas menunjukkan emosi positif, termasuk menunjukkan semangat, optimis, rasa ingin tahu, dan keterikatan terhadap kegiatan tersebut. Sebaliknya, siswa yang tidak terlibat adalah siswa yang menujukkan emosi negatif seperti marah, bosan, cemas, bahkan menunjukkan depresi.Keterlibatan kognitif terjadi ketika individu memiliki strategi dan dapat mengatur dirinya sendiri (self regulating). Siswa yang terlibat secara kognitif memiliki keinginan untuk terlibat dalam belajar dan memiliki keinginan untuk menguasai pengetahuan (Fredricks dkk, 2004).

Berdasarkan definisi keterlibatan siswa dari para ahli di atas, dalam penelitian ini menggunakan definisi keterlibatan siswa yang dikembangkan oleh Fredricks dkk (2004) karena telah mencakup ketiga dimensi keterlibatan siswa yaitu keterlibatan perilaku, keterlibatan emosi dan keterlibatan kognitif dimana ketiga dimensi tersebut yang tertanam dalam diri individu siswa bukan merupakan proses yang terpisah. Sehingga dalam penelitian ini yang dimaksud dengan keterlibatan siswa adalah partisipasi aktif siswa seperti berusaha, bersungguhsungguh, konsentrasi, memberi perhatian, mematuhi peraturan, dan menggunakan strategi regulasi diri dalam kegiatan belajar disertai dengan emosi positif.

Percaya diri merupakan suatu keyakinan dan sikap seseorang terhadap kemampuan pada dirinya sendiri dengan menerima secara apa adanya baik positif maupun negatif yang dibentuk dan dipelajari melalui proses belajar dengan tujuan untuk kebahagiaan dirinya. Seseorang yang percaya diri dapat menyelesaikan tugas atau pekerjaan yang sesuai dengan tahapan perkembangan dengan baik, merasa berharga, mempunyai keberanian, dan kemampuan untuk meningkatkan prestasinya, mempertimbangkan berbagai pilihan, serta membuat keputusan sendiri merupakan perilaku yang mencerminkan percaya diri (Lie, 2003). 
Suheri (2005) menjelaskan bahwa percaya diri adalah keyakinan atas kemampuan diri sendiri dan segala potensi yang dimiliki untuk melakukan sesuatu. Menurut Lauster (2007) kepercayaan diri merupakan suatu sikap atau keyakinan atas kemampuan diri sendiri sehingga dalam tindakan-tindakannya tidak terlalu cemas, merasa bebas untuk melakukan hal-hal yang sesuai keinginan dan tanggung jawab atas perbuatannya, sopan dalam berinteraksi dengan orang lain, memiliki dorongan prestasi serta dapat mengenal kelebihan dan kekurangan diri sendiri. Lauster menggambarkan bahwa orang yang mempunyai kepercayaan diri memiliki ciri-ciri tidak mementingkan diri sendiri (toleransi), tidak membutuhkan dorongan orang lain, optimis dan gembira.

Ada beberapa istilah yang terkait dengan persoalan percaya diri, yaitu :

1. Self-concept : bagaimana seseorang menyimpulkan diri secara keseluruhan, bagaimana seseorang melihat potret diri secara keseluruhan, bagaimana seseorang mengkonsepsikan diri secara keseluruhan.

2. Self-esteem : sejauh mana seseorang punya perasaan positif terhadap diri, sejauh mana seseorang punya sesuatu yang dirasakan bernilai atau berharga, sejauh mana seseorang meyakini adanya sesuatu yang bernilai, bermartabat atau berharga di dalam diri.

3. Self efficacy : sejauh mana seseorang punya keyakinan atas kapasitas yang dimiliki untuk bisa menjalankan tugas atau menangani persoalan dengan hasil yang bagus (to succeed). Ini yang disebut dengan general self-efficacy. Atau juga, sejauh mana seseorang meyakini kapasitas di bidang urusan tertentu. Ini yang disebut dengan specific self-efficacy.

4. Self-confidence: sejauh mana seseorang punya keyakinan terhadap penilaian atas kemampuan diri dan sejauh mana seseorang bisa merasakan adanya "kepantasan" untuk berhasil. Self confidence itu adalah kombinasi dari self esteem dan self-efficacy.

Berdasarkan teori di atas dapat disimpulkan bahwa percaya diri (self confidence) termasuk di dalamnya self-efficacy merupakan sikap individu yang yakin akan kemampuannya sendiri untuk bertingkah laku sesuai dengan yang diharapkannya sebagai suatu perasaan yang yakin pada tindakannya, bertanggung jawab terhadap tindakannya dan tidak terpengaruh oleh orang lain. Orang yang memiliki kepercayaan diri mempunyai ciri-ciri: toleransi, tidak memerlukan dukungan orang lain dalam setiap mengambil keputusan atau mengerjakan tugas, selalu bersikap optimis dan dinamis, serta memiliki dorongan prestasi yang kuat.

Berbagai karakteristik individu yang memiliki kepercayaan diri telah banyak diungkapkan oleh beberapa ahli. Menurut Lauster (2007) terdapat beberapa karakteristik untuk menilai kepercayaan diri individu, diantaranya:

1. Percaya kepada kemampuan sendiri, yaitu suatu keyakinan atas diri sendiri terhadap segala fenomena yang terjadi yang berhubungan dengan kemampuan individu untuk mengevaluasi serta mengatasi fenomena yang terjadi tersebut.

2. Bertindak mandiri dalam mengambil keputusan, yaitu dapat ber-tindak dalam meng-ambil keputusan terhadap apa yang dilakukan secara mandiri tanpa adanya keterlibatan orang lain. Selain itu, mempunyai kemampuan untuk meyakini tindakan yang diambilnya tersebut.

3. Memiliki konsep diri yang positif, yaitu adanya penilaian yang baik dari dalam diri sendiri, baik dari pandangan maupun tindakan yang dilakukan yang menimbulkan rasa positif terhadap diri sendiri. 
4. Berani mengungkapkan pendapat, yaitu adanya suatu sikap untuk mampu mengutarakan sesuatu dalam diri yang ingin diungkapkan kepada orang lain tanpa adanya paksaan atau hal yang dapat menghambat pengungkapan perasaan tersebut.

Menurut Lauster (2007) sebagaimana dikutip oleh Ghufron (2010) orang yang memiliki kepercayaan diri yang positif adalah :

1. Keyakinan akan kemampuan diri yaitu sikap positif seseorang tentang dirinya bahwa mengerti sungguh sungguh akan apa yang dilakukannya.

2. Optimis yaitu sikap positif seseorang yang selalu berpandangan baik dalam menghadapi segala hal tentang diri, harapan dan kemampuan.

3. Obyektif yaitu orang yang percaya diri memandang permasalahan atau segala sesuatu sesuai dengan kebenaran semestinya, bukan menurut kebenaran pribadi atau menurut dirinya sendiri.

4. Bertanggung jawab yaitu kesediaan seseorang untuk menanggung segala sesuatu yang telah menjadi konsekuensinya.

5. Rasional dan realistis yaitu analisa terhadap suatu masalah, suatu hal, sesuatu kejadian dengan mengunakan pemikiran yang diterima oleh akal dan sesuai dengan kenyataan.

Berdasarkan uraian di atas, maka dapat disimpulkan bahwa ciri-ciri dan aspek yang dimiliki oleh orang yang percaya diri yaitu mandiri, optimis, yakin akan kemampuan diri, memiliki konsep diri yang positif, berani bertindak dan mengambil setiap kesempatan yang dihadapi, obyektif, rasional/realistis dan bertanggung jawab atas segala sesuatu yang dilakukannya.

Literasi ekonomi merupakan alat yang berguna untuk merubah perilaku dari tidak cerdas menjadi cerdas. Seperti bagaimana memanfaatkan pendapatan untuk menabung, berinvestasi, proteksi dan memenuhi kebutuhan hidup. Mathews (1999) menyatakan bahwa literasi ekonomi sebagai kemampuan individu untuk mengenali dan menggunakan konsep-konsep ekonomi dan cara berpikir ekonomi untuk memperbaiki dan mendapatkan kesejahteraan. Makna kemampuan (ability) mengindikasikan bahwa pemahaman literasi ekonomi dihasilkan melalui proses belajar yang berkesinambungan sehingga dapat dikatakan bahwa literasi keuangan merupakan bagian juga dari literasi ekonomi.

Salemi (2005) mendefinisikan literasi ekonomi sebagai pemahaman dan penerapan konsepdasar ekonomi dalam situasi nyata bukan hanya berbasis kelas. Dengan demikian, dalam bahasa sederhana literasi ekonomi adalah pengetahuan dan pemahaman konsep dasar ekonomi, prinsip-prinsip, dan aspek pengetahuan ekonomi praktis yang diperoleh di kelas.

Beberapa pihak telah mengembangkan teori pengukuran terhadap literasi ekonomi yang tidak hanya ditinjau dari aspek pengetahuan saja, melainkan lebih pada aspek aplikasi konsep dasar ekonomi sebagaimana yang dikembangkan oleh The Council for Economic Education, John C. Soper and William Walstad, Joint Council on Economic Education, North Central Regional Education Laboratory, dan juga Federal Reserve Bank of Minneapolis.

Berikut ini adalah kriteria/indikator literasi ekonomi yang dikembangkan oleh The Council for Economic Educatioan: a) Mampu menganalisis permintaan barang; b) Mampu menjelaskan peran wirausaha; c) Mampu menganalisis pengaruh tingkat bunga terhadap kecenderungan menabung masyarakat; d) Mampu menjelaskan pendapatan individu; e) Mampu menjelaskan pendapatan 
nasional; f) Mampu menganalisis perubahan penawaran dan perubahan permintaan; g) Mampu menganalisis dampak kebijakan perdagangan internasional; h) Mampu menganalisis dampak kebijakan pemerintah dalam penetapan harga; i) Mampu menjelaskan peranan pelaku ekonomi, produsen, konsumen, dan pemerintah dalam perekonomian; j) Mampu menjelaskan manfaat dari perdagangan internasional; k) Mampu menganalisis dampak perubahan permintaan/penawaran terhadap harga barang; 1) Mampu menjelaskan penggunaan sumber daya yang terbatas; m) Mampu menjelaskan peran pasar modal dalam perekonomian; n) Mampu menganalisis biaya dan keuntungan dari transaksi ekonomi; o) Mampu menganalisis biaya dan keuntungan dari pengambilan keputusan; p) Mampu menjelaskan peranan pemerintah dalam perekonomian.; q) Mampu menjelaskan anggaran pendapatan dan belanja negara; r) Mampu menganalisis dampak inflasi; s) Mampu menganalisis pengembangan industri; t) Mampu menjelaskan fungsi uang.

Tabel 2. Indikator Literasi Ekonomi

\begin{tabular}{|c|c|c|c|}
\hline No & $\begin{array}{c}\text { Silabus IPS } \\
(\text { Sub-sub Tema })\end{array}$ & $\mathrm{CEE}$ & $\begin{array}{c}\text { Indikator } \\
\text { Literasi Ekonomi }\end{array}$ \\
\hline 1 & Kewirausahaan & $\begin{array}{l}\text { Mampu menjelaskan } \\
\text { peran wirausaha }\end{array}$ & $\begin{array}{l}\text { Pengaplikasian peran } \\
\text { wirausaha }\end{array}$ \\
\hline 2 & Monopoli dalam perdagangan & $\begin{array}{l}\text { Mampu menganalisis } \\
\text { perubahan penawaran dan } \\
\text { perubahan permintaan }\end{array}$ & $\begin{array}{l}\text { Pengaplikasian } \\
\text { perubahan permintaan } \\
\text { dan penawaran }\end{array}$ \\
\hline 3 & $\begin{array}{l}\text { Peran Kelembagaan dalam } \\
\text { pengelolaan sumber daya alam: } \\
\text { a. Lembaga Operator; b. } \\
\text { Lembaga Regulator; c.Lembaga } \\
\text { Kontrol (Peme-rintah dan non } \\
\text { Pemerintah) }\end{array}$ & $\begin{array}{l}\text { Mampu menjelaskan } \\
\text { peranan pelaku ekonomi, } \\
\text { produsen, konsumen, dan } \\
\text { pemerintah dalam } \\
\text { perekonomian. }\end{array}$ & $\begin{array}{l}\text { Pengaplikasian peranan } \\
\text { pelaku ekonomi dalam } \\
\text { perekonomian }\end{array}$ \\
\hline No & $\begin{array}{c}\text { Silabus IPS } \\
\text { (Sub-sub Tema) }\end{array}$ & $\mathrm{CEE}$ & $\begin{array}{c}\text { Indikator } \\
\text { Literasi Ekonomi }\end{array}$ \\
\hline 4 & $\begin{array}{l}\text { Pengaruh keunggulan lokasi } \\
\text { terhadap kegiatan komunikasi } \\
\text { (Perdagangan online) } \\
\text { Perdagangan antar Negara }\end{array}$ & $\begin{array}{l}\text { Mampu menjelaskan } \\
\text { manfaat dari perdagangan } \\
\text { internasional. }\end{array}$ & $\begin{array}{l}\text { Pengaplikasian manfaat } \\
\text { perdagangan } \\
\text { internasional }\end{array}$ \\
\hline 5 & Monopoli dalam perdagangan & $\begin{array}{l}\text { Mampu menganalisis } \\
\text { dampak perubahan } \\
\text { permintaan/penawaran } \\
\text { terhadap harga barang. }\end{array}$ & $\begin{array}{l}\text { Pengaplikasian dampak } \\
\text { perubahan permintaan } \\
\text { dan penawaran terhadap } \\
\text { harga barang }\end{array}$ \\
\hline 6 & $\begin{array}{l}\text { Fungsi dan peran sumber daya } \\
\text { alam dalam Pembangunan } \\
\text { Ekonomi }\end{array}$ & $\begin{array}{l}\text { Mampu menjelaskan } \\
\text { penggunaan sumber daya } \\
\text { yang terbatas }\end{array}$ & $\begin{array}{l}\text { Pengaplikasian } \\
\text { penggunaan sumber daya } \\
\text { yang terbatas }\end{array}$ \\
\hline 7 & Prinsip \&Politik Ekonomi & $\begin{array}{l}\text { Mampu menganalisis } \\
\text { biaya dan keuntungan dari } \\
\text { pengambilan keputusan. }\end{array}$ & $\begin{array}{l}\text { Pengaplikasian analisa } \\
\text { biaya dan keuntungan } \\
\text { dalam pengambilan } \\
\text { keputusan }\end{array}$ \\
\hline 8 & $\begin{array}{l}\text { Uang dan lembaga keuangan } \\
\text { dalam perdagangan }\end{array}$ & $\begin{array}{l}\text { Mampu menjelaskan } \\
\text { fungsi uang. }\end{array}$ & $\begin{array}{l}\text { Pengaplikasian fungsi } \\
\text { uang }\end{array}$ \\
\hline
\end{tabular}

Sumber : Kemendikbud (2014) 
Dalam kurikulum SMP, konsep dasar ekonomi sudah terpadu dengan mata pelajaran IPS. Konsep dasar ekonomi yang diajarkan dalam mata pelajaran IPS SMP tersebut selanjutnya dihubungkan dengan standar indikator literasi ekonomi dari The Council for Economic Education (CEE) untuk dijadikan indikator/dasar pengukuran literasi ekonomi siswa SMP.

Dari data empiris, jelas bahwa kegiatan ekstrakurikuler kewirausahaan memberikan komponen penting dalam pendidikan kewirausahaan. Sedangkan pendidikan kewirausahaan berpengaruh terhadap minat berwirausaha. Sebagaiamana dinyatakan oleh Suharti dan Sirine bahwa salah satu faktor pendorong pertumbuhan kewirausahaan di suatu negara terletak pada peranan perguruan tinggi melalui penyelenggaraan pendidikan kewirausahaan (Suharti \& Sirine, 2011:125). Siswa harus memiliki pengalaman substantif bekerja dengan usaha masyarakat untuk menambah nilai usaha riil. Dimana pengalaman menjalankan kegiatan usaha dalam kegiatan ekstrakurikuler tersebut bisa menumbuhkan minat berwirausaha pada diri siswa.

Hasil penelitian Ekpe \& Mat (2012) menunjukkan bahwa orientasi kewirausahaan (self-efficacy dan pendidikan) memiliki pengaruh positif signifikan terhadap niat kewirausahaan di kalangan mahasiswa bisnis perempuan di Nigeria. Kadarsih dkk (2013) dalam penelitiannya menemukan bahwa faktor yang memengaruhi minat mahasiswa untuk berwirausaha antara lain: a) efikasi diri, b) kebebasan bekerja, c) visioner, d) keahlian, e) ketersediaan modal dan lingkungan sosial, f) kontekstual, dan g) persepsi terhadap figur wirausahawan. Akan tetapi hasil penelitian Indarti dan Rostiani (2008) di tiga negara, yaitu Indonesia, Jepang dan Norwegia menemukan bahwa faktor-faktor yang mempengaruhi intensi kewirausahaan berbeda antara satu negara dengan negara yang lain. Efikasi diri terbukti mempengaruhi intensi mahasiswa Indonesia dan Norwegia. Artinya Efikasi diri tidak terbukti berpengaruh terhadap niat berwirausaha mahasiswa di Jepang.

\section{METODE PENELITIAN}

Pendekatan yang digunakan dalam peneliyian ini adalah pendekatan kuantitatif. Variabel dalam penelitian ini adalah kegiatan ekstrakurikuler $\left(\mathrm{X}_{1}\right)$, percaya diri $\left(\mathrm{X}_{2}\right)$, dan literasi ekonomi $\left(\mathrm{X}_{3}\right)$ sebagai variabel independen, sedangkan minat berwirausaha (Y) sebagai variabel dependen. Populasi dalam penelitian ini adalah seluruh siswa kelas VIII SMP Negeri 28 Surabaya dan SMP Negeri 40 Surabaya yang berjumlah 699 siswa. Sedangkan sampel penelitian ditentukan berdasarkan tabel Isaac dan Michael, sehingga diperoleh sampel sebesar 233. Teknik sampling yang digunakan dalam penelitian ini adalah simple random sampling.

Instrumen pengumpulan data yang digunakan dalam penelitian ini adalah angket. Angket digunakan mengungkap variabel kegiatan ekstrakurikuler, percaya diri, literasi ekonomi dan minat berwirausaha. Metode analisis data yang digunakan dalam penelitian ini adalah analisis deskriptif dan regresi berganda untuk mengetahui pengaruh variabel independen terhadap variabel dependen baik secara parsial maupun secara simultan. Uji validitas dan realibilitas atas instrument penelitian ini menunjukkan hasil bahwa seluruh pernyataan dalam 
instrument penelitian dinyatakan valid dan reliabel. Sedangkan teknik analisis data yang digunakan adalah regresi linier berganda.

\section{HASIL PENELITIAN DAN PEMBAHASAN}

Sebelum dilakukan analisis regresi linier berganda, terlebih dahulu dilakukan uji asumsi klasik yang meliputi uji normalitas, uji multikolinieritas, uji heteroskedastisitas dan uji linieritas. Hasil uji normalitas menunjukkan pola distribusi normal. Pada uji multikolinieritas menunjukkan bahwa ketiga variabel bebas tidak memiliki hubungan multikolinieritas. Dari hasil uji heteroskedastisitas disimpulkan bahwa tidak terdapat gejala heteroskedastisitas. Sedangkan hasil uji linieritas menunjukkan bahwa ketiga variabel bebas mempunyai hubungan linier dengan variabel terikat.

Analisis dalam penelitian ini menggunakan analisis regresi berganda yang berfungsi untuk menganalisis pengaruh variabel kegiatan ekstrakurikuler (X1), percaya diri (X2) dan literasi ekonomi (X3) terhadap minat berwirausaha (Y). Adapun rumus dari regresi linier berganda adalah sebagai berikut:

$$
\mathbf{Y}=\mathbf{a}+\mathbf{b}_{1} \mathbf{X}_{1}+\mathbf{b}_{2} \mathbf{X}_{2}+\mathbf{b}_{3} \mathbf{X}_{3}+\mathbf{e i}
$$

\section{Tabel 3. Output Analisis Regresi}

\begin{tabular}{|c|c|c|c|c|c|c|c|c|c|c|c|}
\hline \multicolumn{12}{|c|}{ Coefficients $^{a}$} \\
\hline \multirow{2}{*}{\multicolumn{2}{|c|}{ Model }} & \multicolumn{2}{|c|}{$\begin{array}{c}\text { Unstandardized } \\
\text { Coefficients }\end{array}$} & \multirow{2}{*}{$\begin{array}{c}\text { Standardized } \\
\text { Coefficients } \\
\text { Beta }\end{array}$} & \multirow{2}{*}{$\mathrm{t}$} & \multirow{2}{*}{ Sig. } & \multicolumn{3}{|c|}{ Correlations } & \multicolumn{2}{|c|}{$\begin{array}{c}\text { Collinearity } \\
\text { Statistics }\end{array}$} \\
\hline & & $\mathrm{B}$ & $\begin{array}{l}\text { Std. } \\
\text { Error }\end{array}$ & & & & $\begin{array}{l}\text { Zero- } \\
\text { order }\end{array}$ & Partial & Part & Tolerance & VIF \\
\hline \multirow[t]{4}{*}{1} & (Constant) & 14.963 & 2.168 & & 6.902 & .000 & & & & & \\
\hline & $\begin{array}{l}\text { Kegiatan } \\
\text { Ekstrakurikuler }\end{array}$ & .283 & .087 & .234 & 3.240 & .001 & .383 & .209 & .191 & .666 & 1.501 \\
\hline & Percaya Diri & .077 & .091 & .066 & .849 & .397 & .330 & .056 & .050 & .581 & 1.720 \\
\hline & Literasi Ekonomi & .254 & .077 & .242 & 3.290 & .001 & .389 & .212 & .194 & .641 & 1.560 \\
\hline
\end{tabular}

a. Dependent Variable: Minat Wirausaha

Dari hasil analisis tersebut diperoleh persamaan sebagai berikut: $\mathrm{Y}=$ $14.963+0.283 \mathrm{X}_{1}+0.077 \mathrm{X}_{2}+0.254 \mathrm{X}_{3}+$ ei. Dari persamaan tersebut dapat dijelaskan sebagai berikut:

1. Nilai konstanta (a) sebesar 14,963 artinya jika nilai variabel kegiatan ekstrakurikuler $\left(\mathrm{X}_{1}\right)$, variabel percaya diri $\left(\mathrm{X}_{2}\right.$, ) dan literasi ekonomi $\left(\mathrm{X}_{3}\right)$ adalah nol (0), maka variabel minat berwirausaha (Y) sama dengan 14,963.

2. Koefisien regresi variabel kegiatan ekstrakurikuler $\left(\mathrm{X}_{1}\right)$ sebesar 0,283, dengan tingkat sifnifikansi dibawah 5\% yaitu 0,001 . Nilai koefisien regresi positif menunjukkan pengaruh yang searah, artinya jika keterlibatan siswa dalam kegiatan ekstrakurikuler $\left(\mathrm{X}_{1}\right)$ semakin tinggi maka semakin tinggi pula minat berwirausaha siswa. 
3. Koefisien regresi variabel percaya diri $\left(\mathrm{X}_{2}\right)$ sebesar 0,077 , dengan tingkat signifikansi diatas 5\% yaitu 0,397 . Hal ini menunjukkan bahwa tidak ada pengaruh yang signifikan variable percaya diri terhadap variabel minat berwirausaha siswa.

4. Koefisien regresi variabel literasi ekonomi $\left(\mathrm{X}_{3}\right)$ sebesar 0,254 dengan tingkat signifikansi dibawah $5 \%$ yaitu 0,001 , artinya setiap perubahan variabel literasi ekonomi $\left(\mathrm{X}_{3}\right)$ akan berpengaruh positif terhadap minat berwirausaha (Y). Semakin tinggi tingkat literasi ekonomi siswa maka akan semakin tinggi pula minat berwirausaha siswa.

Sedangkan dari hasil uji parsial (Uji t) menunjukkan bahwa:

1. Variabel kegiatan ekstrakurikuler $\left(\mathrm{X}_{1}\right)$ dari hasil analisis regresi linear berganda memperoleh thitung sebesar 3,240 dengan nilai signifikansi 0,001 , maka nilai signifikansi tersebut $<0,05$, sehingga dapat disimpulkan bahwa hasil penelitian ini menolak $\mathrm{H}_{\mathrm{o}}$ dan menerima $\mathrm{H}_{\mathrm{a}}$ dimana variabel kegiatan ekstrakurikuler $\left(\mathrm{X}_{1}\right)$ secara sendirian (parsial) terbukti berpengaruh signifikan terhadap minat berwirausaha.

2. Variabel percaya diri $\left(\mathrm{X}_{2}\right)$ dari hasil analisis regresi linear berganda memperoleh thitung sebesar 0,849 dengan nilai signifikansi 0,397 dimana nilai signifikansi tersebut $>0,05$, sehingga dapat disimpulkan bahwa hasil penelitian ini menerima $\mathrm{H}_{\mathrm{o}}$ dan menolak $\mathrm{H}_{\mathrm{a}}$ yang berarti variabel percaya diri secara parsial tidak berpengaruh signifikan terhadap minat berwirausaha.

3. Variabel literasi ekonomi $\left(\mathrm{X}_{3}\right)$ dari hasil analisis regresi linear berganda memperoleh thitung sebesar 3,290 dengan nilai signifikansi 0,001 dimana nilai signifikansi tersebut $<0,05$, sehingga dapat disimpulkan bahwa hasil penelitian ini menolak $\mathrm{H}_{\mathrm{o}}$ dan menerima $\mathrm{H}_{\mathrm{a}}$ dimana variabel literasi ekonomi secara parsial berpengaruh signifikan terhadap minat berwirausaha.

Selanjutnya, dari hasil Uji Simultan (Uji F) diperoleh F hitung sebesar 19,743 dengan tingkat signifikansi lebih kecil dari 0,05 yaitu 0,000. Maka dapat disimpulkan $\mathrm{H}_{\mathrm{o}}$ ditolak dan $\mathrm{H}_{\mathrm{a}}$ diterima. Hal ini berarti bahwa variabel independen yaitu kegiatan ekstrakurikuler, percaya diri dan literasi ekonomi berpengaruh signifikan secara bersama-sama (simultan) terhadap variabel minat berwirausaha. Dengan demikian, hipotesis yang menyatakan bahwa ada pengaruh signifikan secara bersama-sama (simultan) kegiatan ekstrakurikuler, percaya diri dan literasi ekonomi terhadap minat berwirausaha diterima.

Dari hasil penelitian diatas, dapat dijelaskan pengaruh masing-masing variabel bebas terhadap variabel terikat baik secara parsial maupun secara simultan sebagai berikut:

\section{Pengaruh Kegiatan Ekstrakurikuler Cinta Lingkungan/PLH Terhadap Minat Berwirausaha}

Berdasarkan analisis data yang telah dilakukan, diperoleh hasil bahwa kegiatan ekstrakurikuler berpengaruh signifikan positif terhadap minat berwirausaha Siswa SMP Negeri di Surabaya. Hal ini berarti bahwa semakin tinggi tingkat keterlibatan siswa dalam kegiatan ekstrakurikuler, maka semakin tinggi pula minat berwirausaha siswa. Nilai positif pada variabel ini menunjukkan bahwa kegiatan ekstrakurikuler cinta lingkungan/PLH memiliki hubungan yang searah dengan minat berwirausaha siswa sehingga semakin 
tinggi keterlibatan siswa dalam kegiatan ekstrakurikuler cinta lingkungan/PLH maka semakin tinggi pula minat berwirausaha siswa.

Dari temuan penelitian ini, ketiga indikator variabel kegiatan ekstrakurikuler yaitu keterlibatan perilaku, keterlibatan emosi dan keterlibatan kognitif, menunjukkan bahwa para siswa terlibat sangat aktif dalam kegiatan ekstrakurikuler baik secara perilaku, emosi maupun kognitif. Di sisi lain, variabel minat berwirausaha (Y) ketiga indikatornya yaitu kognitif, afektif dan konatif juga menunjukkan bahwa para siswa memiliki minat yang tinggi untuk berwirausaha. Hal inilah yang menyebabkan variabel kegiatan ekstrakurikuler berpengaruh signifikan terhadap minat berwirausaha.

Pada indikator keterlibatan perilaku, diperoleh temuan bahwa keterlibatan siswa dalam berusaha secara maksimal dalam mencapai hasil belajar baik ketika belajar di dalam kelas maupun ketika belajar di luar kelas dalam kegiatan ekstrakurikuler sangat tinggi. Disamping itu, daya tahan para siswa ketika harus berhadapan dengan tantangan tugas belajar juga menunjukkan hasil yang tinggi. Meskipun keterlibatan para siswa dalam memberikan kontribusi dalam kegiatan ekstrakurikuler diperoleh temuan yang menunjukkan hasil sedang, namun secara umum hasil penelitian ini menunjukkan bahwa keterlibatan perilaku siswa dalam kegiatan ekstrakurikuler cinta lingkungan/PLH adalah tinggi.

Untuk indikator keterlibatan emosi, diperoleh temuan bahwa para siswa memiliki sense of belonging yang tinggi dan merasa menjadi bagian dari kegiatan ekstrakurikuler cinta lingkungaan/PLH. Rasa ikut memiliki dan menjadi bagian dari kegiatan ekstrakurikuler inilah yang akan mempengaruhi keterlibatan emosi para siswa dalam kegiatan ekstrakurikuler/PLH. Selain itu, temuan dalam penelitian ini juga menunjukkan bahwa para siswa telah memberikan penghargaan dan apresiasi yang tinggi pula terhadap keberhasilan atau prestasi yang dicapai oleh sekolah terutama yang terkait dengan kegiatan ekstrakurikuler cinta lingkungan/PLH. Hal ini menunjukkan bahwa para siswa SMP Negeri di Surabaya memiliki keterlibatan emosi yang tinggi dalam kegiatan ekstrakurikuler cinta lingkungan/PLH.

Terkait dengan indikator keterlibatan kognitif, diperoleh temuan yang menunjukkan bahwa siswa terlibat secara aktif (tinggi) dalam kegiatan belajar di kegiatan ekstrakurikuler cinta lingkungan/PLH. Selain itu, para siwa juga mengaku memiliki keinginan yang tinggi untuk menguasai pengetahuan/keterampilan yang diajarkan dalam kegiatan ekstrakurikuler. Hal ini menunjukkan bahwa secara umum para siswa SMP Negeri di Surabaya memiliki keterlibatan kognitif yang tinggi dalam kegiatan ekstrakurikuler cinta lingkungan/PLH.

Hasil penelitian ini mendukung teori tentang kegiatan ekstrakurikuler yang telah dikemukakan oleh Kemendikbud (2013). Penelitian ini telah membuktikan bahwa kegiatan ekstrakurikuler Cinta Lingkungan/PLH SMP Negeri Surabaya bisa digunakan sebagai kegiatan pendidikan untuk mengembangkan bakat dan minat siswa, khususnya minat berwirausaha. Sebagaimana telah dijelaskan oleh Kemendikbud (2013), bahwa ekstrakurikuler adalah kegiatan pendidikan yang dilakukan oleh peserta didik di luar jam belajar kurikulum standar sebagai perluasan dari kegiatan kurikulum dan dilakukan di bawah bimbingan sekolah dengan tujuan untuk 
mengembangkan kepribadian, bakat, minat, dan kemampuan peserta didik yang lebih luas atau di luar minat yang dikembangkan oleh kurikulum.

Hasil penelitian ini menunjukkan bahwa keterlibatan aktif siswa secara perilaku, emosi dan kognitif terbukti dapat menumbuhkan minat berwirausaha siswa. Artinya fungsi dan tujuan kegiatan ekstrakurikuler sebagaimana dimaksud kemendikbud (2013) dapat dicapai melalui keterlibatan perilaku, emosi dan kognitif siswa dalam kegiatan ekstrakurikuler Cinta Lingkungan/PLH yang merupakan bagian dari kegiatan Adiwiyata khususnya di SMP Negeri 28 Surabaya dan SMP Negeri 40 Surabaya.

Hasil Penelitian ini sejalan dengan penjelasan Kemendikbud (2013) dan penelitian Fredricks dkk (2004). Agar kegiatan ekstrakurikuler ini bisa mencapai fungsinya: fungsi pengembangan, fungsi sosial, fungsi rekreatif, fungsi persiapan karir dan juga bisa mencapai tujuannya untuk meningkatkan kemampuan kognitif, afektif dan psikomotor (Kemendikbud, 2013), maka diperlukan adanya keterlibatan aktif dari para siswa. Sedangkan menurut Fredricks dkk (2004) keterlibatan siswa didefinisikan melalui tiga dimensi, yaitu: keterlibatan perilaku (behavior engagement) yang berfokus pada partisipasi siswa seperti berusaha, bersungguh-sungguh, konsentrasi, memberi perhatian, mematuhi peraturan, dan berkontribusi dalam diskusi di kelas, keterlibatan emosi (emotional engagement) yang berfokus pada reaksi emosi siswa, dan keterlibatan kognitif (cognitive engagement) yang berfokus pada investasi siswa dalam belajar dan strategi regulasi diri yang digunakan.

Hasil penelitian ini juga mendukung hasil penelitian/kajian empiris yang dilakukan oleh para peneliti sebelumnya, diantaranya adalah sebagai berikut: Suharti dan Sirine (2011), Robertson dan Collins (2003) yang menyatakan bahwa kegiatan ekstrakurikuler mampu menumbuhkan minat berwirausaha.

Dengan demikian terbukti bahwa keterlibatan aktif siswa dalam kegiatan ekstrakurikuler Cinta Lingkungan/PLH mampu meningkatkan minat berwirausaha siswa. Hal ini ditunjukkan dengan nilai signifikansi positif dalam persamaan regresi dan didukung oleh teori dan kajian empiris.

\section{Pengaruh Percaya Diri Terhadap Minat Berwirausaha}

Berdasarkan analisa data yang telah dilakukan dalam penelitian ini, diperoleh hasil bahwa percaya diri tidak berpengaruh signifikan terhadap minat berwirausaha. Hal ini menunjukkan bahwa tingginya tingkat percaya diri yang dimiliki siswa tidak menjamin tingginya minat berwirausaha siswa tersebut.

Dari temuan penelitian ini, diperoleh temuan bahwa dari delapan indikator percaya diri, ada tiga indikator yang masuk kategori sedang dan lima indikator masuk kategori tinggi. Tiga indikator yang termasuk kategori sedang tersebut adalah, mandiri, optimis dan berani bertindak mengambil setiap kesempatan yang dihadapi. Ketiga indikator tersebut termasuk ciri/karakter utama seorang wirausaha sebagaimana dikatakan Meridith (2000:5-6). Hal inilah yang menjadi penyebab variabel percaya diri tidak berpengaruh signifikan terhadap minat berwirausaha siswa SMPN di Surabaya.

Pada indikator mandiri, diperoleh temuan bahwa hanya sedikit diatas separoh dari siswa yang menjadi sampel penelitian ini memiliki kemandirian yang tinggi sedangkan sisanya menunjukkan tingkat kemandirian yang rendah 
sehingga secara umun tingkat kemandiriant siswa SMP Negeri di Surabaya masuk kategori sedang. Karena tingkat kemandirian yang demikian itulah maka pengaruhnya terhadap minat berwirausaha siswa SMP Negeri di Surabaya sangat kecil mengingat indikator mandiri menurut Meridith (2000:56) termasuk karakter utama seorang wirausahawan.

Pada indikator optimis, secara umum menunjukkan tingkat optimisme yang sedang meskipun sebagian besar siswa menunjukkan tingkat optimisme yang tinggi, namun sebagian kecil menunjukkan tingkat optimisme yang rendah. Hal ini juga menjadi penyebab rendahnya pengaruh percaya diri khususnya indikator optimis terhadap minat berwirausaha siswa SMP Negeri di Surabaya mengingat indikator optimis menurut Meridith (2000) termasuk karakter utama seorang wirausahawan.

Demikian juga dengan indikator berani bertindak dan mengambil setiap kesempatan yang dihadapi, secara umum masuk kategori sedang. Hampir separoh siswa SMP Negeri di Surabaya yang menajdi sampel penelitian ini memiliki tingkat keberanian bertindak dan mengambil setiap kesempatan yang dihadapi yang rendah. Hal ini juga berpengaruh terhadap rendahnya minat berwirausaha siswa SMP Negeri di Surabaya.

Meskipun demikian, siswa SMP Negeri di Surabaya masih memiliki keyakinan yang tinggi akan kemampuan dirinya. Demikian juga dengan indikator-indikator yang lain yaitu konsep diri yang positif, obyektifitas, rasionalitas/realistis dan indikator bertanggung jawab atas segala sesuatu yang dilakukan juga menunjukkan hasil yang tinggi. Sehingga secara umum dari kedelapan indikator yang ada, sebagian besar menunjukkan hasil yang tinggi. Artinya, variabel percaya diri pada siswa SMP Negeri di Surabaya masuk pada tingkatan yang tinggi meskipun belum terbukti berpengaruh secara signifikan terhadap minat berwirausaha.

Hasil penelitian ini mendukung temuan peneliti sebelumnya yaitu Indarti dan Rostiani (2008) tentang intensi berwirausaha di tiga negara, yaitu Indonesia, Jepang dan Norwegia yang menemukan bahwa faktor-faktor yang mempengaruhi intensi kewirausahaan berbeda antara satu negara dengan negara yang lain. Efikasi diri terbukti mempengaruhi intensi mahasiswa Indonesia dan Norwegia. Artinya Efikasi diri tidak terbukti berpengaruh terhadap niat berwirausaha mahasiswa di Jepang.

Meskipun hasil penelitian ini mendukung temuan penelitan Indarti dan Rostiani (2008) diatas, namun penyebab dari tidak adanya pengaruh signifikan percaya diri terhadap minat berwirausaha dari kedua penelitian ini berbeda. Indarti dan Rostiani (2008) menjelaskan bahwa penyebab Jepang memiliki skor nilai total aktivitas kewirausahaan yang paling rendah dibanding Norwegia dan Indonesia adalah karena wirausaha di Jepang menghadapi banyak kesulitan dalam mendirikan usaha baru, peraturan pemerintah sangat ketat, dominasi korporat besar dan bank yang konservatif serta sedikitnya modal bagi pendiri bisnis baru. Sedangkan dalam penelitian ini, ditemukan penyebabnya adalah kurangnya optimisme, kemandirian dan keberanian siswa dalam bertindak mengambil kesempatan yang dihadapi dimana menunjukkan indikator optimis, mandiri dan berani bertindak mengambil kesempatan yang dihadapi memperoleh kategori sedang. Padahal ketiga indikator tesebut adalah karakter utama yang dibutuhkan oleh pelaku wirausaha. 
Hasil penelitian ini tidak mendukung/tidak sesuai dengan penelitian terdahulu, diantaranya yaitu: Ekpe \& Mat (2012), Kadarsih dkk (2013), Samydevan dkk (2015). Dengan demikian hipotesis yang menyatakan diduga ada pengaruh percaya diri terhadap minat berwirausaha siswa SMP Negeri di Surabaya tidak dapat diterima.

\section{Pengaruh Literasi Ekonomi Terhadap Minat Berwirausaha}

Berdasarkan analisis regresi linier berganda yang telah dilakukan dalam penelitian ini, diperoleh hasil bahwa literasi ekonomi berpengaruh positif dan signifikan terhadap minat berwirausaha siswa. Nilai positif pada variabel ini menunjukkan bahwa literasi ekonomi memiliki hubungan yang searah dengan minat berwirausaha siswa. Sehingga dapat dideskripsikan bahwa semakin tinggi literasi ekonomi yang dimiliki siswa, dalam hal ini adalah literasi ekonomi yang berkaitan dengan konsep dasar ekonomi tingkat SMP, maka semakin tinggi pula minat berwirausaha siswa.

Dari temuan dalam penelitian ini, tampak bahwa dari delapan indikator variabel literasi ekonomi, enam diantaranya masuk kategori tinggi dan hanya dua indikator yang masuk kategori sedang, yaitu indikator perubahan permintaan/penawaran terhadap harga dan indikator manfaat perdagangan internasional. Dari dua indikator berkategori sedang itu pun ada satu indikator yang mendekati kategori tinggi, yaitu indikator perubahan permintaan/penawaran terhadap harga. Sedangkan untuk variabel minat berwirausaha, dari tiga indikator, semuanya masuk kategori tinggi. Sehingga secara umum dapat disimpulkan bahwa siswa SMP Negeri di Surabaya telah memiliki tingkat literasi ekonomi yang tinggi.

Pada indikator peran wirausaha (mengaplikasikan salah satu karakter yang dimiliki oleh wirausaha yang berupa kreatifitas) menunjukkan bahwa hampir semua siswa yang menjadi responden dalam penelitian ini memiliki tingkat kreatifitas yang tinggi. Sedangkan pada indikator pengaplikasian perubahan penawaran dan permintaan menunjukkan hasil sedang. Meskipun demikian, ternyata hasil penelitian ini juga menemukan bahwa lebih dari separoh siswa yang menjadi responden penelitian ini memperoleh nilai ratarata yang tinggi pada indikator tersebut.

Untuk indikator pengaplikasian peranan pelaku ekonomi dalam perekonomian menunjukkan hasil yang tinggi. Hal ini menunjukkan bahwa pemahaman siswa SMP Negeri di Surabaya terhadap konsep peran pelaku ekonomi dalam perekonomia sudah sangat baik. Namun demikian, pada indikator pengaplikasian manfaat dari perdagangan internasional, siswa SMPNegeri di Surabaya masih mendapatkan nilai rata-rata sedang terutama pada konsep manfaat perdagangan internasional sebagai penyuplai kebutuhan barang dan jasa yang belum bisa dibuat di dalam negeri. Meskipun begitu, ternyata pada indikator yang sama, pemahaman siswa SMP Negeri di Surabaya terhadap konsep pengaplikasian manfaat perdagangan internasional sebagai pendorongpenyerapan tenaga kerja dan penerimaan pajak menunjukkan hasil yang tinggi.

Pada indikator pengaplikasian dampak perubahan permintaan/ penawaran terhadap harga, ditemukan bahwa siswa SMP Negeri di Surabaya sudah memiliki tingkat pemahaman yang tinggi. Demikian juga dengan 
indikator pengaplikasian penggunaan sumber daya yang terbatas diperoleh hasil yang menunjukkan bahwa siswa SMP Negeri di Surabaya telah memiliki tingkat pemahaman yang sangat baik.

Terkait dengan indikator pengaplikasian analisa biaya dan keuntungan dalam pengambilan keputusan, hasil penelitian ini menemukan bahwa siswa SMP Negeri di Surabaya telah memiliki tingkat pemahaman yang baik. Sedangkan pada indikator pengaplikasian fungsi uang ditemukan data yang menunjukkan bahwa siswa SMP Negeri di Surabaya telah memiliki pemahaman yang sangat baik terhadap konsep ekonomi yang terkait dengan pengaplkasian fungsi uang.

Dari uraian di atas terlihat bahwa secara umum siswa SMP Negeri di Surabaya telah memiliki tingkat literasi ekonomi yang tinggi. Di sisi lain, penelitian ini juga menemukan hasil yang menunjukkan bahwa minat berwirausaha siswa SMP Negeri di Surabaya juga tinggi. Hal inilah yang menunjukkan bahwa variabel literasi ekonomi berpengaruh signifikan terhadap minat berwirausaha siswa SMP Negeri di Surabaya.

Hasil penelitian ini mendukung teori tentang literasi ekonomi sebagaimana telah dijabarkan dalam aplikasi konsep dasar ekonomi yang terdapat dalam konsep dasar ekonomi SMP dan kriteria literasi ekonomi yang dikembangkan oleh The Council for Economic Educatioan. Beberapa teori yang didukung oleh hasil penelitian ini diantaranya adalah sebagai berikut: Mathews (1999), Pandey \& Bhattacharya (2012), Salemi (2005) yang menyatakan bahwa literasi ekonomi berpengaruh terhadap minat berwirausaha.

Berdasarkan hasil temuan dalam penelitian ini dan hasil penelitian/ kajian empiris terdahulu maka terbukti bahwa literasi ekonomi mampu meningkatkan minat berwirausaha siswa. Hal ini ditunjukkan dengan nilai signifikansi positif dalam persamaan regresi dan didukung oleh teori dan kajian empiris.

\section{Pengaruh Kegiatan Ekstrakurikuler Cinta Lingkungan/PLH, Percaya Diri dan Literasi Ekonomi Terhadap Minat Berwirausaha}

Berdasarkan hasil analisis data yang dilakukan menunjukkan bahwa variabel kegiatan ekstrakurikuler cinta lingkungan/PLH, percaya diri dan literasi ekonomi secara simultan berpengaruh positif dan signifikan terhadap minat berwirausaha siswa SMP Negeri di Surabaya. Hal ini berarti semakin tinggi tingkat keterlibatan siswa dalam kegiatan ekstrakurikuler cinta lingkugan/PLH, semakin tinggi tingkat percaya diri siswa dan semakin tinggi literasi ekonomi siswa maka semakin tinggi pula minat wirausahanya. Sebaliknya, semakin rendah tingkat keterlibatan siswa dalam kegiatan ekstrakurikuler cinta lingkungan/PLH, semakin rendah tingkat percaya diri siswa dan semakin rendah literasi ekonomi siswa maka semakin rendah pula minat berwirausahanya.Akan tetapi secara parsial ketiga variabel bebas tersebut memiliki pengaruh yang berbeda terhadap minat berwirausaha.

Kegiatan ekstrakurikuler secara simultan mempunyai pengaruh yang lebih tinggi terhadap minat berwirausaha siswa dibandingkan dengan dua variabel bebas yang lain yaitu percaya diri dan literasi ekonomi. Hasil penelitian ini menunjukkan bahwa sebagian besar siswa memiliki keterlibatan yang tinggi dalam kegiatan ekstrakurikuler cinta lingkungan/PLH baik 
keterlibatan perilaku, keterlibatan emosi maupun keterlibatan kognitif. Dari ketiga indikator kegiatan ekstrakurikuler cinta lingkungan/PLH tersebut, indikator keterlibatan emosi menunjukkan hasil yang lebih tinggi dibanding kedua indikator yang lain. Sedangkan indikator keterlibatan perilaku menunjukkan hasil yang paling rendah dibanding kedua indikator yang lainnya. Sementara indikator keterlibatan kognitif menunjukkan hasil yang lebih tinggi dibanding keterlibatan perilaku dan lebih rendah dibanding keterlibatan emosi.

Percaya diri memiliki pengaruh yang paling rendah terhadap minat berwirausaha siswa bila dibandingkan dengan dua variabel bebas yang lain yaitu kegiatan ekstrakurikuler cinta lingkungan/PLH dan literasi ekonomi. Hasil penelitian ini menunjukkan bahwa secara umum rasa percaya diri siswa SMP Negeri di Surabaya berada pada level tinggi. Akan tetapi ternyata pengaruhnya secara parsial terhadap minat berwirausaha sangat rendah meskipun secara simultan bersama variabel yang lain berpengaruh signifikan terhadap minat berwirausaha.

Literasi ekonomi mempunyai pengaruh yang lebih tinggi terhadap minat berwirausaha bila dibandingkan dengan pengaruh percaya diri dan lebih rendah bila dibandingkan dengan pengaruh kegiatan ekstrakurikuler terhadap minat berwirausaha. Hasil penelitian ini menunjukkan bahwa secara umum siswa SMP Negeri di Surabaya telah memiliki tingkat literasi ekonomi yang tinggi. Hal ini terlihat dari tingkat pemahaman siswa yang tinggi terhadap berbagai konsep dasar ekonomi yang meliputi: peran wirausaha (mengaplikasikan salah satu karakter wirausaha yang berupa kreatifitas), pengaplikasian perubahan penawara dan permintaan, pengaplikasian peranan pelaku ekonomidalam perekonomian, pengaplikasian manfaat dari perdagangan internasional, pengaplikasian dampak perubahan permintaan/penawaran terhadap harga, pengaplikasian penggunaan sumber daya yang terbatas, pengaplikasian analisa biaya dan keuntungan dalam pengambilan keputusan dan pengaplikasian fungsi uang.

Dari hasil penelitian yang diuraikan diatas menunjukkan bahwa kegiatan ekstrakurikuler cinta lingkungan/PLH, percaya diri dan litersi ekonomi secara simultan memberikan pengaruh positif dan signifikan terhadap minat berwirausaha siswa SMP Negeri di Surabaya.

\section{SIMPULAN}

Berikut ini akan dipaparkan simpulan dari hasil penelitian ini berdasarkan pembahasan yang telah diuraikan disimpulkan bahwa ada pengaruh signifikan kegiatan ekstrakurikuler secara parsial terhadap minat berwirausaha siswa SMP Negeri di Surabaya. Hal ini menunjukkan bahwa kegiatan ekstrakurikuler cinta lingkungan/PLH dapat meningkatkan minat berwirausaha siswa SMP Negeri di Surabaya. Sedangkan variabel percaya diri secara parsial tidak mempunyai pengaruh signifikan terhadap minat berwirausaha siswa SMP Negeri di Surabaya. Hal ini menunjukkan bahwa meningkatnya tingkat percaya diri siswa tidak menjamin meningkatnya minat berwirausaha siswa SMP Negeri di Surabaya. Variabel literasi ekonomi berpengaruh signifikan secara parsial terhadap minat berwirausaha siswa SMP Negeri di Surabaya. Hal ini menunjukkan bahwa meningkatnya literasi ekonomi berpengaruh terhadap 
meningkatnya minat berwirausaha siswa SMP Negeri di Surabaya. Secara bersama-sama ada pengaruh signifikan kegiatan ekstrakurikuler, percaya diri dan literasi ekonomi terhadap minat berwirausaha siswa SMP Negeri di Surabaya. Hal ini menunjukkan bahwa semakin tinggi tingkat keterlibatan siswa dalam kegiatan ekstrakurikuler cinta lingkungan/PLH, percaya diri dan literasi ekonomi maka semakin tinggi pula minat berwirausaha siswa.

\section{DAFTAR RUJUKAN}

Alma, B. (2013). Kewirausahaan Untuk Mahasiswa dan Umum. Bandung: Alfabeta.

As'ad, Moh. (2004). Psikologi Industri: Seri ilmu Sumber Daya Manusia. Yogyakarta: Liberty.

Budiati,Yuli I, Tri Endang Yani, Nuria Universari. (2012). Minat Mahasiswa Menjadi Wirausaha (Studi Pada Mahasiswa Fakultas Ekonomi Universitas Semarang). J. Dinamika Sosbud Volume 14 Nomor 1, Juni 2012 : 89 - 101 Issn 1410-9859

Ekpe, Isidore \& Norsiah Mat. (2012). "The Moderating Effect of Social Environment on the Relationship between Entrepreneurial Orientation and Entrepreneurial Intentions of Female Students at Nigerian Universities". International Journal of Management Sciences and Business Research, 2012, Vol. 1, No. 4, Pp 1-16 (ISSN: 2226-8235)

Fredricks, J.A., Blumenfeld, P.C., \& Paris, A. H., (2004). School Engagement: Potential of the Concept, State of the Evidence. Review of Educational Research, Volume 74, No. 1,pp.59-109.

Fuadi, Iski Fadli. (2009). "Hubungan Minat Berwirausaha dengan Prestasi Praktik Kerja Industri Siswa kelas XII Teknik Otomotif SMK Negri 1 Adiwerna Kabupaten Tegal.” Jurnal PTM Volume 9,Desember 2009,hlm 92-98.

Ghufron M. Nur, Rini Risnawati S. (2010). Teori-teori Psikologi. YogJakarta:Ar Ruz Media

Gregov, Zrinka, Ljiljana Bratnar Kovačević. (2004). Building Competitive Advantage: The Role Of Small Business Schools. 2nd International Conference An Enterprise Odyssey: Building Competitive Advantage, Zagreb-Croatia, June 17-19, 2004, Pp 113-119.

Hisrich, R. D., \& Petters, Michael P. (2008). Entrepreneurship, Edisi 7. Jakarta: Salemba Empat.

Indarti, Nurul dan Rokhima Rostiani. (2008). "Intensi Kewirausahaan Mahasiswa: Studi Perbandingan Antara Indonesia, Jepang dan Norwegia". Jurnal Ekonomika dan Bisnis Indonesia, Vol. 23, No. 4, Oktober 2008. Manuscript hal. 1-27

Kadarsih, Retno, Susilaningsih, Sri Sumaryati. (2012) "Faktor-Faktor Yang Memengaruhi Minat Berwirausaha PadaMahasiswa Program Studi Pendidikan EkonomI FKIP UNS”Jupe UNS, Vol 2 No 1 Tahun 2013 Hal $95 \mathrm{~s} / \mathrm{d} 106$

Kemendikbud. (2013). Lampiran III Peraturan Menteri Pendidikan Dan Kebudayaan Republik Indonesia Nomor 81a Tahun 2013 Tentang Implementasi Kurikulum- Pedoman Kegiatan Ekstrakurikuler. Jakarta: Kemendikbud 
Kemendikbud. (2014). Silabus Mata Pelajaran IPS Kurikulum 2013. Jakarta: Kemendikbud

Lambing, P. \& Kuehl. C. R. (2007). Entrepreneurship. 4th edition. Upper Saddle River: Prentice Hall.

Lauster, Peter.(2007). Tes Kepribadian terjemahan D.H. Gulo. Jakarta: Gramedia Lie, Anita. (2003). Menumbuhkan Percaya Diri Pada Anak. Jakarta: Gramedia.

Mahesa, A \& Rahardja, E. (2012)." Analisis Faktor-faktor Motivasi yang Mempengaruhi Minat Berwirausaha”. Diponegoro Journal of Management, 1,1, 130-137.

Mathews, L. G. (1999). Promoting economic literacy: ideas for your classroom. Paper prepared for the 1999 AAEA annual meeting Nashville, Tennessee

Meridith, Geof ey G. (2000). Kewirausahaan: Teori dan Praktik. Jakarta: PT. Pustaka Binaman Pressindo.

Pandey, Chanchala \& S. B. Bhattacharya. (2012). Economic Literacy Of Senior Secondary School Teachers: A Field Study. Journal Of All India Association For Educational Research Vol. 24, No. 1, June 2012

Robertson, M. and Collins, A. (2003), The video role models as an enterprise teaching aid. Education+Training, Vol. 45 Iss: 6, pp.331-340

Salemi, Michael K. (2005).Teaching Economic Literacy: Why, What and How. International Review of Economics Education, volume 4, issue 2 (2005), pp. $46-57$

Samydevan, Vijeyan, ShishiKumar Piaralal, Abd Kadir Othman and Zahir Osman. (2015). "Impact of Psychological Traits, Entrepreneurial Education and Culture in Determining Entrepreneurial Intention among Pre-University Students in Malaysia”. American Journal of Economics 2015, 5(2): 163-167

Slameto. (2010). Belajar dan Faktor-faktor yang Mempengaruhinya. Jakarta: Rineka Cipta.

Suharti, L \& Sirine, H. (2011). "Faktor-faktor yang Berpengaruh terhadap Niat Kewirausahaan (Studi terhadapMahasiswa Universitas Kristen SatyaWacana Salatiga)". Jurnal Manajemendan Kewirausahaan, vol.13, no. 2, september 2011: 124-134

Suheri. (2005).Jangan Cuma Bermimpi, Mulai Saja! Jakarta: Penerbit Quantum Bisnis \& Manajemen (PT. Mizan Pustaka)

Sumarwan, Ujang. (2003). Perilaku Konsumen : Teori dan Penerapannya dalam Pemasaran. Cetakan Pertama.Jakarta: Ghalia Indonesia.

Wibowo, Budhi, Adi Kusrianto. (2010). Menembus Pasar Ekspor, Siapa Takut. Jakarta : Elex Media Komputindo.

Yunus, N. K. Y, Ishak, S. \& Jalil, N. A. (2010) "Economic Literacy amongst the Secondary School Teachers in Perak Malaysia". Information Managementand Business Review Vol. 1, No. 2, pp. 69-78, Dec 2010 